\title{
Recorregut de recerca geològica i mineralògica per la comarca de la Cerdanya: des de Puigcerdà cap a La Tor de Querol, Porte i cap a les mines de Pimorent
}

Josep Maria Mata-Perelló

Joaquim Sanz Balagué
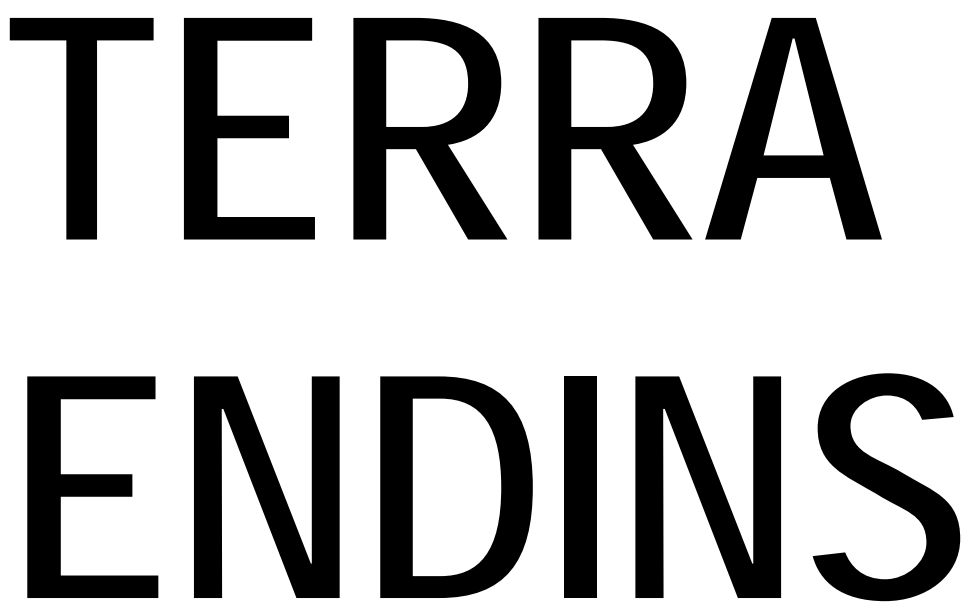

\section{REVISTA DE GEOLOGIA}

n. 1

MARÇ 2015 


\title{
RECORREGUT DE RECERCA GEOLÒGICA I MINERALÒGICA PER LA COMARCA DE LA CERDANYA: DES DE PUIGCERDÀ CAP A LA TOR DE QUEROL, PORTE I CAP A LES MINES DE PIMORENT
}

\author{
Josep Maria Mata-Perelló \\ Museu de geologia Valentí Masachs, Escola Politècnica Superior d'Enginyeria de Manresa \\ (EPSEM), Universitat Politècnica de Catalunya · BarcelonaTech (UPC), 08272 Manresa, Spain
}

\section{Joaquim Sanz Balagué}

Departament d'Enginyeria Minera i Recursos Naturals (EMRN), Escola Politècnica Superior d'Enginyeria de Manresa (EPSEM), Universitat Politècnica de Catalunya . BarcelonaTech (UPC), 08272 Manresa, Spain

Paraules clau: Patrimoni geològic i miner; Mines de ferro; Cerdanya; materials neògens ; Morfologia glacial

\section{Resum}

Recorregut realitzat el 3 d juliol del 2013. En aquesta ocasió, el recorregut de l'itinerari discorrerà, en la seva totalitat pel Sistema Pirinenc. I més concretament ho farà per tres sectors diferenciats: per una banda per l'extrem septentrional del Mantell del Cadí, (prop del seu contacte amb la Depressió de la Cerdanya); per d'altra, a través d'aquesta depressió acabada d'esmentar; i finalment, a través dels denominats Apilaments Antiformes de la Zona Axial Pirinenca (i més concretament pels sectors corresponents al Massís dels Tres Senhors).

Així, el recorregut s'iniciarà dintre de la Depressió de la Cerdanya, per la qual es transitarà en el primer tram del recorregut, entre les localitats de Puigcerdà i Enveig. Per d'altra banda, el recorregut entre la població d'Enveig i les Mines de Ferro de Pimorent (situades prop del port del mateix nom), s'endinsarà pels Apilaments Antiformes de la Zona Axial Pirinenca, els quals es troben situats al Nord de la Depressió de la Cerdanya.

També cal dir que la totalitat del recorregut es farà dintre de la comarca de la Cerdanya, començant a la Baixa Cerdanya i finalitzant a l'Alta, però prop de la seva frontera amb Andorra i amb el País de Foix. 


\section{Objectius fonamentals}

Es centraran en els aspectes geològics, geomorfològics i mineralògics que apuntarem a continuació:

1.- Observació de la Depressió de la Cerdanya, per la qual discorrerà part del recorregut de l'itinerari entre les poblacions de Puigcerdà (Baixa Cerdanya) i Enveig (Alta Cerdanya), a l'inicia del recorregut.

2.- Observació dels materials neògens al llarg del recorregut de l'itinerari. Aquests materials pertanyen fonamentalment al Pliocè, al Pleistocè i a l'Holocè.

3.- Observació de l'estructura dels Apilaments Antiformes de la Zona Axial Pirinenca, per entre la qual discorrerà el recorregut de l'itinerari, en els seus darrers trams, entre Enveig i la fi del recorregut.

4.- Observació dels afloraments dels materials paleozoics (amb presència de terrenys del Cambro-Ordovicià al Carbonífer), que formen part dels relleus pirinencs que constitueixen els Apilaments Antiformes de la Zona Axial. Aquests materials es tallaran al llarg de la zona esmentada a l'apartat anterior.

5.- Observació a distancia de l'estructura de la Zona Sudpirinenca, i més concretament del seu Mantell del Cadí. Aquesta unitat es troba situada al Sud del recorregut de l'Itinerari.

6.- Reconeixement de diverses mineralitzacions situades al llarg del recorregut, com les mineralitzacions ferruginoses associades a skarn, situades a Pimorent (Alta Cerdanya), entre els materials del Cambro-ordovicià. Aquestes mineralitzacions es localitzen dintre de la zona dels Apilaments Antiformes de la Zona Axial.

7.- Reconeixement de les antigues explotacions mineres, relacionades amb les mineralitzacions esmentades a l'apartat anterior. Alhora, també observarem altres explotacions, com les relacionades amb roques granítiques, prop de la Tor de Querol.

8.- Observació dels impactes produïts per les explotacions anteriors, sobre el Medi Natural i sobre el Medi Ambient.

9.- Observació, al llarg del recorregut, dels diferents indrets relacionats amb el Patrimoni Geològic. En concret, cal parlar del relacionat amb la morfologia glacial que se observarà en bona part del recorregut. Tot i així, en els darrers trams del recorregut, serà possible veure la morfologia glacial de l'alta vall del riu Arieja.

10.- Observació, al llarg del recorregut, dels diferents indrets relacionats amb el Patrimoni Miner. Així, cal fer esment de l'interessant patrimoni miner de les Mines de ferro de Pimorent. També caldria parlar de les nombroses fargues catalanes escampades per diversos llocs d'aquestes comarques de la Cerdanya.

\section{Antecedents}

En relació a aquest recorregut, hi ha alguns antecedents nostres; concretament dels següents: Mata-Perelló (1995a, 1995b, 1997, 1998, 1999, 2005, 2009 i 2010), als quals ens remetem. En aquests treballs es fa referència a uns itineraris geològics i mineralògics coincidint en part amb el present. Tret dels anteriors, no coneixem cap altre antecedent bibliogràfic, pel que fa als itineraris. 
Pel que toca al coneixement de les estructures geològiques que veurem en aquest itinerari hi ha l'antecedent local de Berastegui et altri (1993); aquest antecedent es relatiu a un treball de I'IGME, relatiu a l'àrea recorreguda. Altres antecedents, de caràcter estructurals, i relatius al conjunt dels Països Catalans, són els següents: Riba et altri (1976) i Guimerà (1982); així com SGC (1990). Finalment, i pel que fa a les mineralitzacions que trobarem al llarg del recorregut, ens referirem a: Mata-Perelló (1991), en un estudi relatiu al conjunt de les mineralitzacions catalanes.

Evidentment, totes aquestes referències bibliogràfiques, figuraran degudament relacionades, per ordre alfabètic, dintre de l'apartat dedicat a les referències bibliogràfiques.

\section{Recorregut de l'itinerari}

El recorregut d'aquest itinerari s'iniciarà a la capital comarcal, a Puigcerdà, situada dintre de la Depressió de la Cerdanya. Tot seguit, el recorregut es dirigirà cap a la Guingueta, des d'on s'agafarà la carretera francesa $\mathrm{N}-20$, fins prop d'Enveig, on es farà una nova aturada. Prop d'aquest indret es deixarà la Depressió de la Cerdanya, per on ha transcorregut fins ara el recorregut de l'itinerari.

Després es continuarà, ja dintre dels Apilaments Antiformes de la Zona Axial, i s'anirà cap a la Tor de Querol i Porta (encara dintre de l'Alta Cerdanya), per tal d'anar cap al Coll de Pimorent. Des d'aquest indret, es farà una fillola per tal d'anar fins a les Mines de Ferro de Pimorent, on es farà una parada, finalitzant aquí el recorregut de l'itinerari.

\section{Advertiments previs}

Com en altres recorreguts de recerca geològica i mineralògica ..., si es disposa del temps suficient, poden efectuar-se passant per totes les parades i filloles. En cas contrari, recomanem prescindir de les anomenades parades - condicionals.

També recomanem que es demani informació sobre l'estat dels diferents trams de les pistes forestals, per les quals s'ha de circular, en el recorregut de l'itinerari, per tal d'evitar problemes secundàries. En aquesta ocasió, el recorregut transitarà per un tram dificultós: el que ens conduirà des del Port de Pimorent cap a la mina de ferro del mateix nom. aquesta ocasió, aquest recorregut el farem a peu.

Per d'altra banda, i a l'igual que en altres recorreguts semblants, recomanem tenir el màxim de cura i de respecte, entorn de la Natura que ens rodeja.

\section{Descripció de l'itinerari}

En aquest recorregut hem situat, com ja és habitual en tots els itineraris, una sèrie d'estacions o de parades, que anirem veient a continuació. En cada cas, els hi donarem una denominació que podrà correspondre a algun paratge proper. També indicarem el terme municipal i la comarca on es troba. Per d'altra banda, en cadascuna de les parades, indicarem entre parèntesi el número del mapa topogràfic, a escala 1:50.000, on es troba situada la parada considerada.

En aquesta ocasió utilitzarem una doble nomenclatura: per una banda, si s'escau, utilitzarem algun dels dos fulls següents de la CME ("Cartografia Militar de España"): 216 (o de Bellver de Cerdanya) i 217 (o de Puigcerdà). I, per d'altra banda, també utilitzarem un dels fulls IGN ("Institut Géograpgique National"); concretament del següent: 2149 (o de Fontargenta). 
Així, passarem a continuació, a fer una referència ordenada, de les diferents aturades que composen el recorregut del present itinerari.

\subsection{Parada 1. Corva de la Torre de Gelabert, (terme municipal d'Ur, comarca de la Cerdanya, Catalunya). (Full 2249 de I'IGN, i 217 de la CME).}

Tot i que el recorregut de l'itinerari s'haurà iniciat a Puigcerdà (la capital comarcal, situada al bell mig de la Depressió de la Cerdanya), ens caldrà anar cap a veïna localitat de la Guingueta, utilitzant la carretera N-152. Després des d'aquesta darrera població ens caldrà agafar la carretera francesa $\mathrm{N}-20$, per on es passarà aviat per Ur.

Poc després d'aquest poble, cal parar a la Corba de la Torre de Gelabert, abans d'arribar al poble d'Enveig. Si s'escau, des de Puigcerdà. pot agafar-se la carretera que es dirigeix a Llívia, i passant (abans d'arribar-hi) a l'esmentada N-20, procedent de la Guingueta. En el primer cas, s'haurà efectuat un recorregut proper als $5 \mathrm{~km}$, des de clínic. En el segon cas, haurà estat sols d'uns $4 \mathrm{Km}$.

Tot aquest recorregut s'ha efectuat íntegrament per entre els materials neògens de la Depressió de la Cerdanya, arriben fins prop de la vorera meridional dels Apilaments Antiformes de la Zona Axial, prop de la qual ara ens trobem.

Per d'altra banda, des d'aquest indret, es pot gaudir d'una immillorable perspectiva de la depressió acabada d'esmentar. Aquesta depressió es troba reomplerta de materials terciaris neògens. Tanmateix, des d'aquí es poden veure els relleus del Mantell del Cadí, tot formant els cims de: la Tossa d'Alp, el Moixeró, Penyes Altes de Moixeró, ..., situats al sud de l'esmentada depressió.

\subsection{Parada 2. Gravera de Querol, (terme municipal de Querol, comarca de la Cerdanya, Catalunya). (Full 2249 de I'IGN, i 217 de la CME).}

Després de realitzar l'aturada anterior, cal continuar per la carretera N-20, anant successivament cap a Enveig, la Tor de Querol, Riutés, Ques, Curbassil, i Querol. En arribar a darrer poble, que caldrà sobrepassar amb escreix, arribarem a un pont de la carretera sobre el riu Querol. En aquest indret farem una nova aturada, a uns $12 \mathrm{Km}$ de la darrerament efectuada.

En aquest recorregut hem anat remuntant l'esmentat riu Querol, fins arribar a l'indret on ara estem situats. Aquest riu és afluent del riu Segre, per les immediacions de Puigcerdà, a la Guingueta.

Per d'altra banda, ja des del començament d'aquest tram del recorregut, es passa sempre pels Apilaments Antiformes de la Zona Axial Pirinenca, havent deixat enrere la Depressió de la Cerdanya, a la parada anterior. Així, en bona part del recorregut afloren els granits i les granodiorites del Pic de la Mina de Pimorent; així com trams esquistosos de l'Ordovicià i del Cambro-Ordovicià. Precisament, en aquest lloc hi ha un aflorament de les granodiorites ( $i$ granits) acabats d'esmentar. Aquests materials es troben força alterats i transformats en sauló.

Aquests materials estan sent explotats en aquest lloc, en una gravera, la qual es troba en actiu. Tot i així, cal dir que aquesta no és la única que existeix en aquest indret. Des de la carretera es pot fer una bona observació d'aquesta explotació. Tot i així, si es vol visitar, cal demanar autorització a l'empresa explotadora. (fotografia 1) 


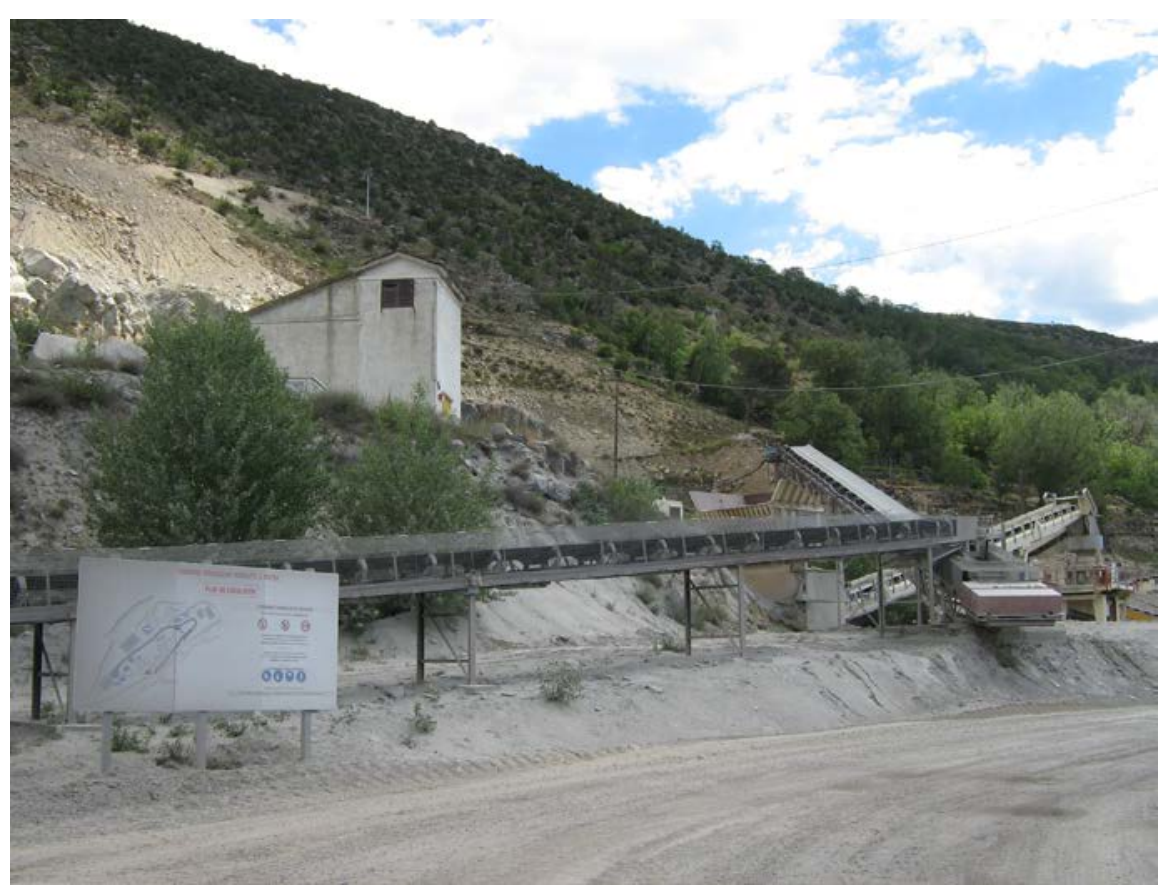

FOTOGRAFIA 1. Vista de la gravera

\subsection{Parada 3 - condicional. Estany de Passet, (terme municipal de Portè - Pimorent, comarca de la Cerdanya, Catalunya). (Full 2149 de I'IGN i 183 de la CME).}

Des de la parada anterior, cal continuar per la carretera francesa N-20 tot anant, ara cap a Porta i cap a Portè. Després, des d'aquesta darrera població cal agafar el camí - carreter (que surt per la dreta) i que es va dirigint cap a l'Estany de Passet (Ėtang de Passet). A uns $4 \mathrm{Km}$ de I'inici d'aquest camí, arribarem a aquest estany. Així, des de la parada anterior, haurem recorregut uns $9 \mathrm{Km}$ i escaig.

En aquest recorregut, hem circulat sempre pels Apilaments Antiformes de la Zona Axial Pirinenca. Així, en bona part del recorregut afloren els granits i les granodiorites del Pic de la Mina de Pimorent; així com trams esquistosos de l'Ordovicià i del Cambro-Ordovicià.

Bona part del recorregut l'hem fet entre paratges força interessants, amb una morfologia glacial molt ben desenvolupada. Precisament, en aquest indret hi ha un estany de morfologia glacial. Tot i això, aquesta morfologia ha estat lleugerament modificada, com a conseqüència de les labors artificial de recreixement de l'estany. (fotografia 2).

\subsection{Parada 4. Coll de Pimorent, (terme municipal de Portè - Pimorent, comarca de la Cerdanya, Catalunya). (Full 2149 de I'IGN i 183 de la CME).}

Des de la parada anterior, cal continuar per la carretera francesa N-20 tot anant, ara cap a Porta i cap a Portè. Després, des d'aquesta darrera població cal ascendir cap al Coll de Pimorent. En arribar a aquest indret farem una nova aturada, a uns $12 \mathrm{Km}$ de la sortida i de d'anterior. 
En aquest recorregut, hem circulat sempre pels Apilaments Antiformes de la Zona Axial Pirinenca. Així, en bona part del recorregut afloren els granits i les granodiorites del Pic de la Mina de Pimorent; així com trams esquistosos de l'Ordovicià i del Cambro-Ordovicià.

Bona part del recorregut l'hem fet entre paratges força interessants, amb una morfologia glacial molt ben desenvolupada. Així, a l'indret de la present aturada es pot fer una bona observació d'aquesta morfologia, amb profunds valls glacials: el de l'Arieja pel Nord i el del Querol pel Sud. Tanmateix, en aquest recorregut hem observat uns interessants depòsits de morrenes glacials, com pels voltants de Portè, de Porta i de la Tor de Querol; així com a les rampes de pujada cap al Coll de Pimorent, on ara som.

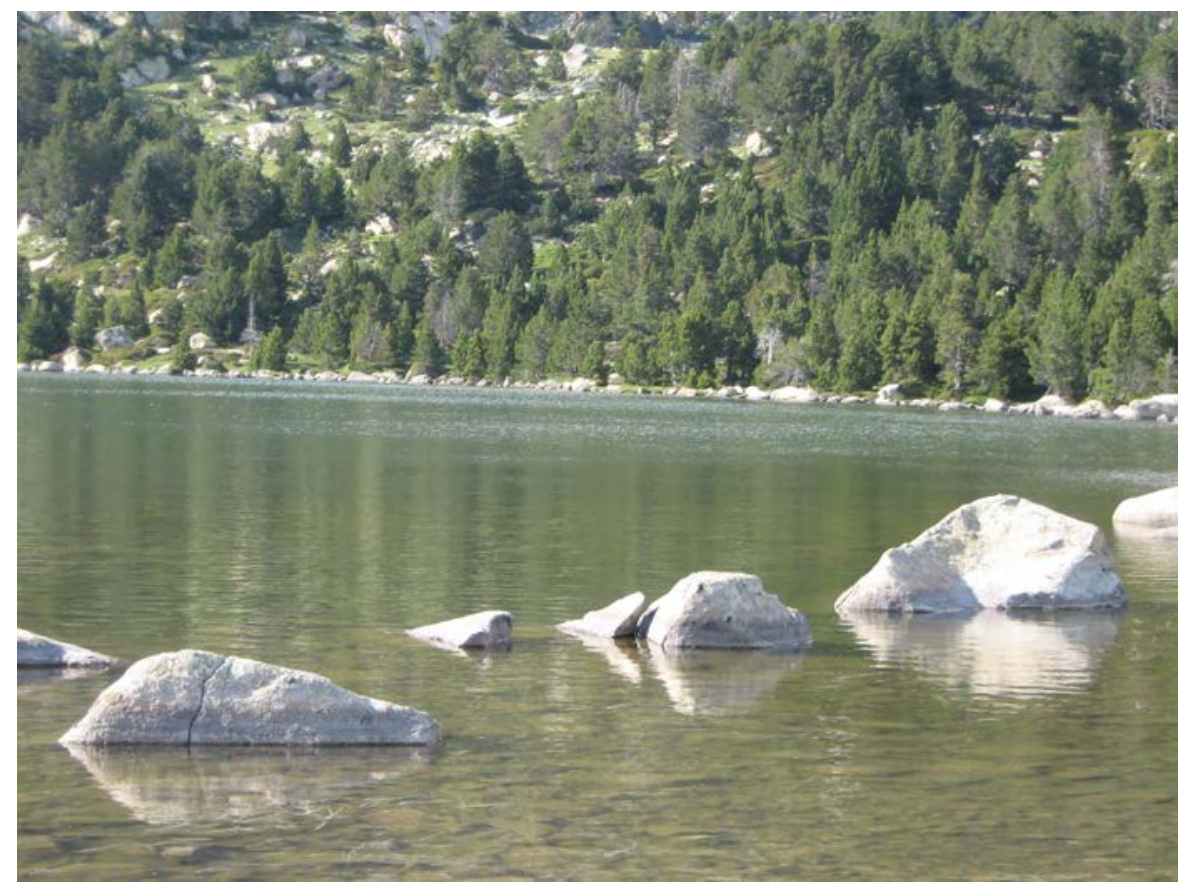

FOTOGRAFIA 2. Estany de Passet

\subsection{Parada 5. Cami cap a les mines, vall de I'Arieja, (terme municipal de Portè - Pimorent, comarca de la Cerdanya, Catalunya). (Full 2149 de I'IGN i 183 de la CME).}

Des de la parada anterior, cal continuar pel camí que es dirigeix cap a les Mines de Pimorent, el qual surt des del mateix coll. Aquest camí s'adreça cap a ponent. Aproximadament a uns 3 $\mathrm{Km}$ del coll (i a uns $2 \mathrm{Km}$ abans d'arribar a les esmentades mines) es pot realitzar una nova aturada.

En aquest recorregut, sempre dintre dels Apilaments Antiformes de la Zona Axial Pirinenca. Així, haurem trobat en bona part del recorregut afloren els granits i les granodiorites del Pic de la Mina de Pimorent; així com trams esquistosos de I'Ordovicià i del Cambro-Ordovicià.

Per d'altra part, des d'aquest recorregut es pot fer una bona observació de la vall glacial per on discorre el riu Arieja, al Nord d'on som. Un bon lloc per efectuar aquesta observació es I'indret 
de l'aturada, poc abans de trobar un camí que se'n va cap a la part alta de les explotacions mineres. (fotografia 3).

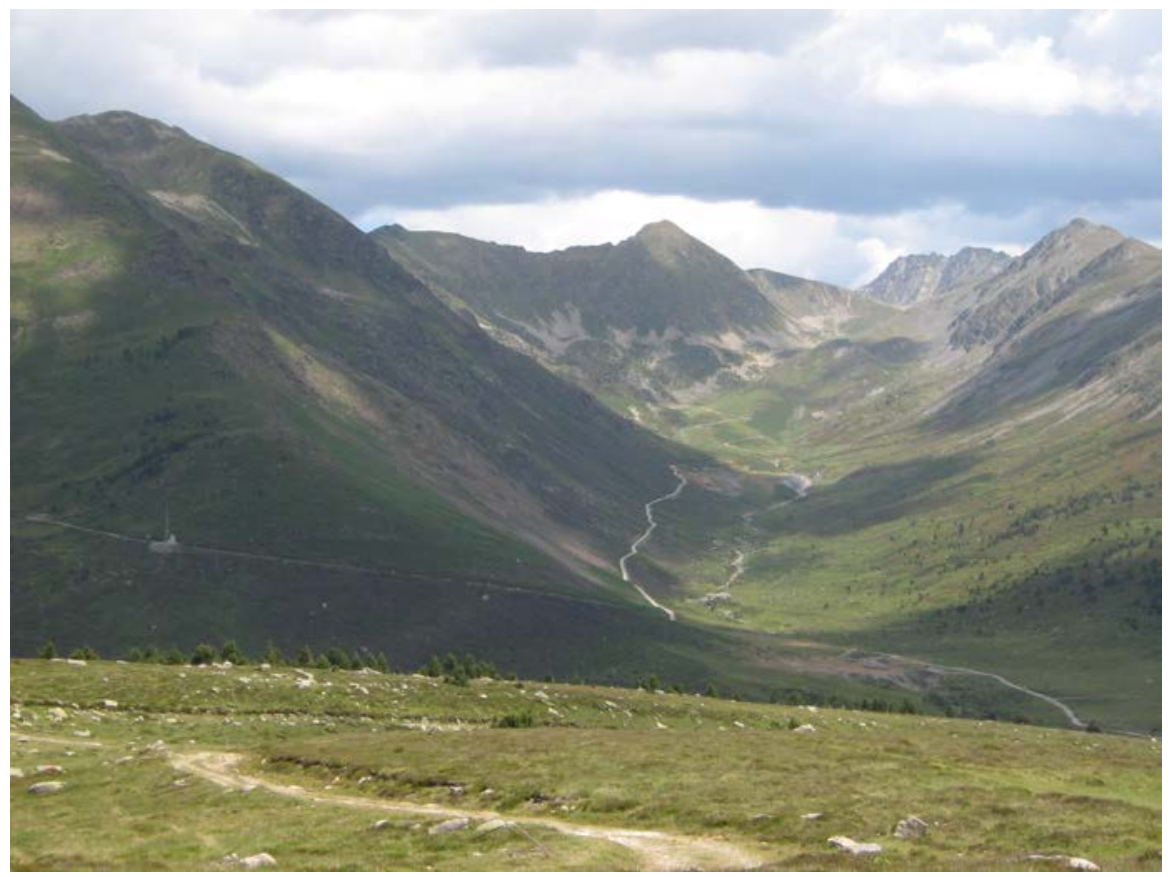

FOTOGRAFIA 3. Vall de I'Arieja, des del camí a les Mines de Pimorent

\subsection{Parada 6. Instal-lacions de les mines de ferro de Pimorent (terme municipal de Porté-Pimorent, comarca de la Cerdanya, Catalunya). (Full 2149 de I'IGN i 183 de la CME).}

Des d'aquest indret cal continuar cap a les Mines de Pimorent, les quals es troben a uns $2 \mathrm{Km}$ de la parada anterior. Aquí efectuarem una nova aturada-

Com al recorregut anterior, hem anat circulant entre els Apilaments Antiformes de la Zona Axial Pirinenca. Així, en bona part del recorregut afloren els granits i les granodiorites del Pic de la Mina de Pimorents; així com trams esquistosos de l'Ordovicià i del Cambro-Ordovicià.

En arribar a l'indret de la mina, haurem trobat algunes de les construccions mineres, en un precari estat de conservació. Tot i així, aquestes instal-lacions constitueixen un element important del nostre patrimoni miner. Així, haurem vist tot un grapat d'edificis (oficines, habitacions, dutxes, zones de calefacció). (fotografies 4 i 5 ).

També haurem trobat restes de les tolves, plans inclinats, cables del telefèrics, que en conjunt formen part d'un important patrimoni miner, pel qual cal vetllar, almenys per tal de conservar el que queda. 

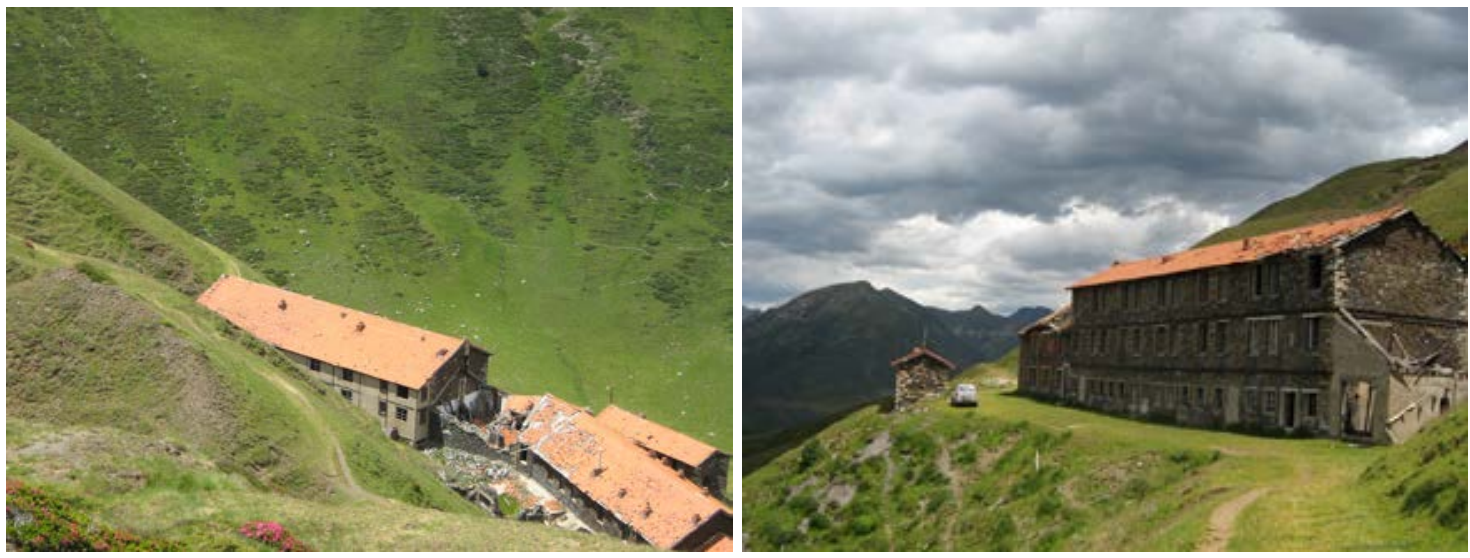

Fotografies 4 i 5 . Dues visions de les instal-lacions mineres

\subsection{Parada 7. Explotacions de les mines de ferro de Pimorent (terme municipal de Portè - Pimorent, comarca de la Cerdanya, Catalunya). (Full 2149 de I'IGN i 183 de la CME).}

Després de fer l'aturada anterior, sols ens cal anar cap a les antigues explotacions mineres. Aquestes es troben situades per sobre dels edificis que hem vist a la parada anterior, al Sud dels mateixos, però al seu costat.

Pel que fa a es explotacions, cal dir que en bona part, les que veiem es van efectuar a cel obert, sobre unes mineralitzacions associades a skarn, que es situen al contacte entre uns nivells carbonatats que pertanyen a l'Ordovicià, y les granodiorites abans esmentades. Aquesta mineralització va ésser explotada amb la intenció de beneficiar els minerals de ferro, i va gaudir d'una certa importància, durant el passat segle i a principis d'aquest. A l'actualitat encara es conserven (fotografies 6 i 7).

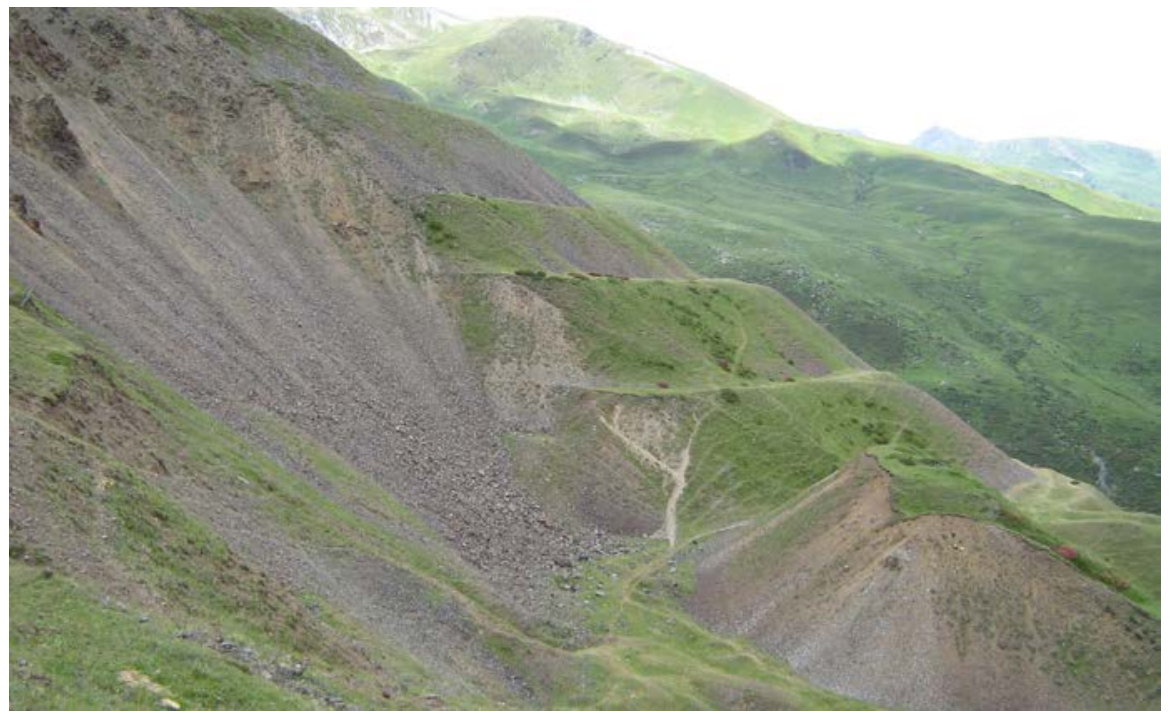

FOTOGRAFIA 6. Les explotacions mineres

Terra endins.2015 n.1 | Recorregut de recerca geològica i mineralògica per la comarca de la Cerdanya: des de Puigcerdà cap a La Tor de Querol, Porte i cap a les mines de Pimorent 
Entre els minerals de ferro, cal fer esment de la presència de: magnetita (que va ésser el mineral explotat), magheimita i siderita. Com a mineral d'alteració, força abundant, també cal fer esment de la goethita (normalment terrosa, en forma de "limonita").

També es troba present l'hematites. Per d'altra banda, igualment es troben al skarn altres minerals com: actinolita, granats (sense identificar), i tremolita, entre molts altres minerals.

Pel que fa a les explotacions, cal dir que es troben situades per una gran extensió, amb nombroses escombreres per tot arreu.

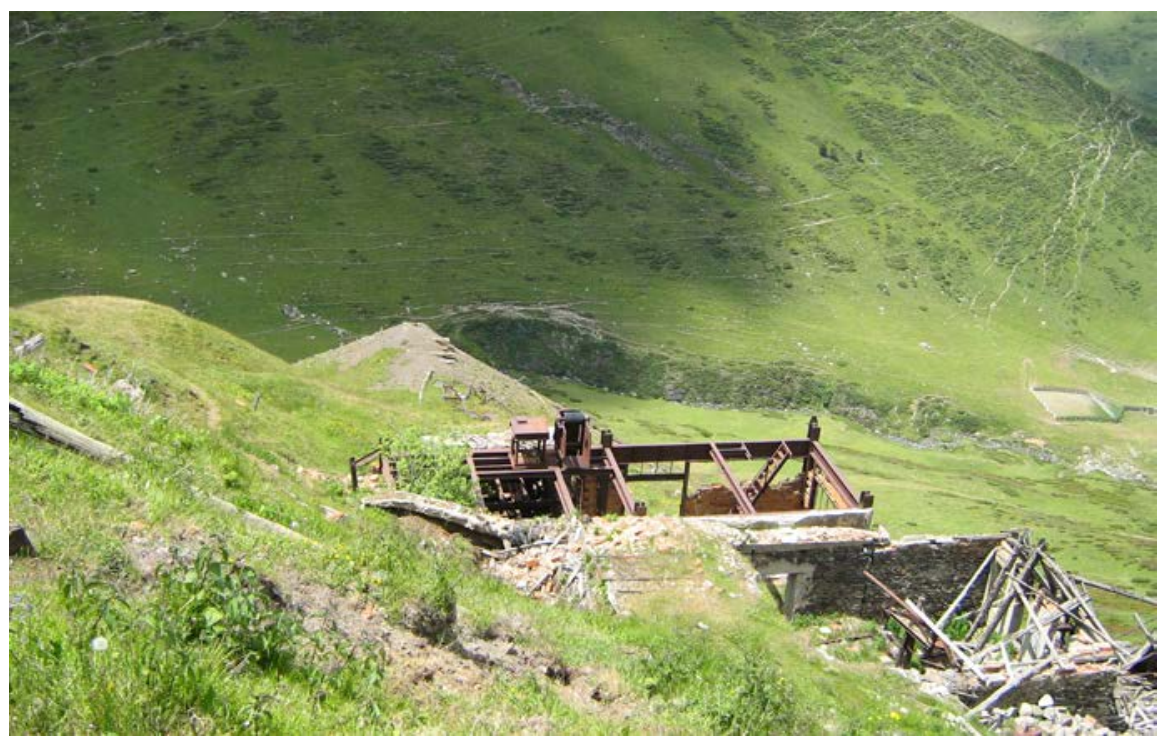

FOTOGRAFIA 7. Un aspecte de la pèrdua de patrimoni

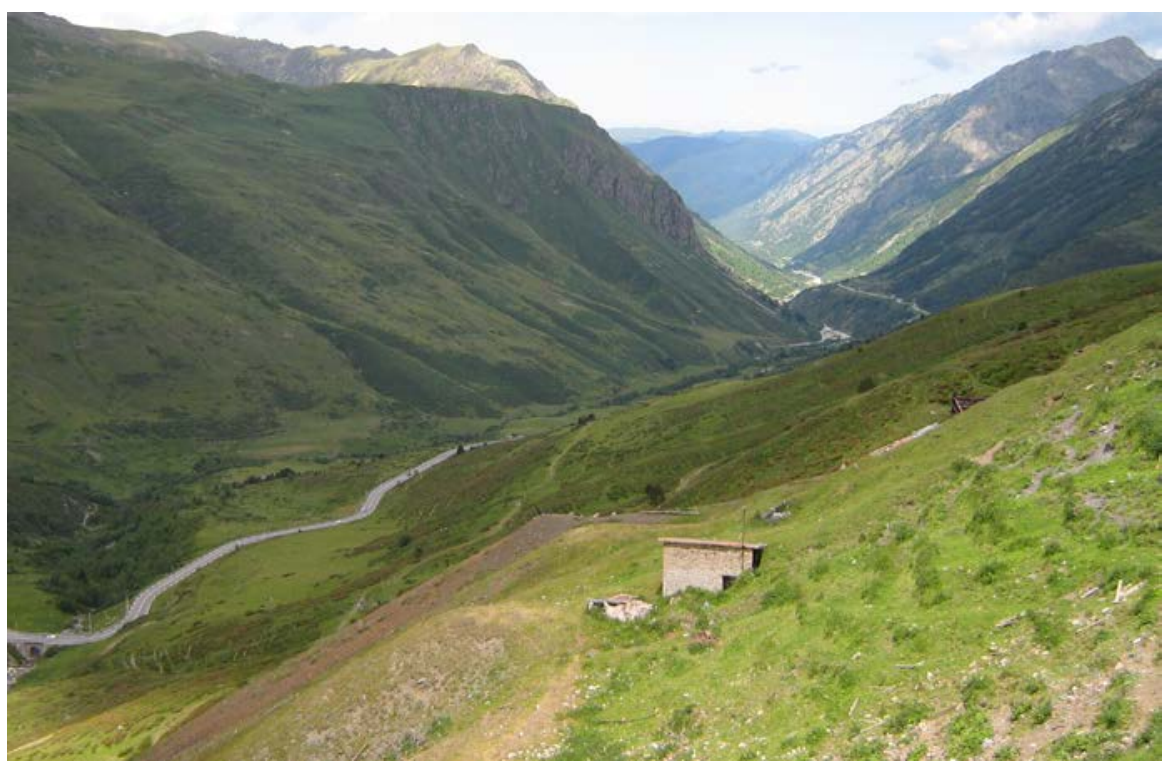

FOTOGRAFIA 8. Vall de l'Arieja des de les mines 
El recorregut de l'itinerari finalitza en aquest lloc

\section{Bibliografia emprada}

BERASTEGUI, X. et altri ( 1993).- Tall geològic del Pirineu central. Servei Geològic de Catalunya, Institut Cartogràfic de Catalunya. Col-lecció 1:200.000. Barcelona

GUIMERÀ, J. et altri (1992).- Geologia (II), Història Natural dels Països Catalans, Vol. 2, 547 pag. Enciclopèdia Catalana, S.A. Barcelona

MATA-PERELLÓ, J.M. (1991).- Els Minerals de Catalunya. Arxius de la Secció de Ciències, t. XCIII, 442 pag. Institut d’Estudis Catalans. Barcelona

MATA-PERELLÓ,J.M. (1995a).- Selecció d’itineraris geològico - mineralògics per l'Alt Urgell, el Solsonès, la Cerdanya i Andorra. Xaragall, $n^{\circ}$. 36, 33 pàg. Manresa

MATA-PERELLÓ, J.M. (1995b).- Recerca Geològica i Mineralògica per la Cerdanya, pel País de Saut i pel País de Foish. Xaragall, sèrie $B, n^{\circ} 21,12$ pàg. Manresa

MATA-PERELLÓ, J.M. (1997).- Recerca geològica i minera per les comarques del Berguedà, de la Cerdanya i de l' Alt Urgell: des de Berga a Alàs. Inèdit, 12 pàgines. Manresa

MATA-PERELLÓ, J.M. (1998).- Recorregut de recerca geològica i minera per les comarques de la Cerdanya i de I'Alt Urgell: des de PI i des de Sansor a Pimorent i a Toloriu, Inèdit, 12 pàgines. Manresa

MATA-PERELLÓ, J.M. (1999).- Recorregut de recerca geològica i mineralògica per la comarca de la Cerdanya: des de Puigcerdà a Pimorent, a Pi i a l'Estany de la Pera. Inèdit. 12 pag. Manresa

MATA-PERELLÓ, J.M. (2005).- Recorregut de recerca geològica i mineralògica per la comarca de la Cerdanya: des de Puigcerdà a Puimorén; i des d'Enviny a Pi, i a l'Estany de la Pera i a Toloriu. Inèdit. 12 pag. Manresa

MATA-PERELLÓ, J.M. (2009).- Recorregut de recerca geològica i mineralògica per la comarca de la Cerdanya: des de Puigcerdà cap a Porte i cap a Pimorent. Inèdit. 6 pàgines. Manresa

MATA-PERELLÓ, J.M. (2010).- Recorregut de recerca geològica i mineralògica per la comarca de la Cerdanya: des de Puigcerdà cap a la Tor de Querol, Porte i cap a Pimorent. Inèdit. 11 pàgines. Manresa

MATA-PERELLÓ, J.M. i SANZ BALAGUÉ, J. (1993).- Guia de Identificación de Minerales, adaptada fundamentalmente a la Península Ibérica. Parcir, Edicions Selectes. 205 pàgines. Manresa

RIBA ARDERIU, O. Et altri. (1976).- Geografia Fisica dels Països Catalans. Edit Ketres, 254 pàgines. Barcelona

SGC (1990).- Mapa Geològic de Catalunya a escala 1:250.000, Servei Geològic de Catalunya (Inst. Cartograf. de Catalunya). Barcelona 